\title{
Choroid Plexus Epithelium of the Lateral Ventricle
}

National Cancer Institute

\section{Source}

National Cancer Institute. Choroid Plexus Epithelium of the Lateral Ventricle. NCI

Thesaurus. Code C49248.

The epithelium of the choroid plexus at the lateral ventricle; which consists of cuboidal cells. 